\title{
Extremely low threshold-current-density InGaAs quantum-well lasers with emission wavelength of 1215-1233 nm
}

\author{
Nelson Tansu, ${ }^{\text {a) }}$ Jeng-Ya Yeh, and Luke J. Mawst \\ Reed Center for Photonics, Department of Electrical and Computer Engineering, \\ University of Wisconsin-Madison, 1415 Engineering Drive, Madison, Wisconsin 53706-1691
}

(Received 6 January 2003; accepted 10 April 2003)

\begin{abstract}
Extremely low threshold-current-density $\mathrm{In}_{0.4} \mathrm{Ga}_{0.6}$ As quantum-well $(\mathrm{QW})$ lasers have been realized in the 1215-1233 $\mathrm{nm}$ wavelength regime. The measured room-temperature threshold current density of the InGaAs QW lasers with a cavity length of $1000 \mu \mathrm{m}$ is only $90 \mathrm{~A} / \mathrm{cm}^{2}$ at an emission wavelength of $1233 \mathrm{~nm}$. (C) 2003 American Institute of Physics. [DOI: 10.1063/1.1581978]
\end{abstract}

Conventional $1300 \mathrm{~nm}$ lasers are based on the InGaAsP or InGaAlAs quantum-well (QW) active material system on an InP substrate. ${ }^{1}$ Unfortunately, these $1300 \mathrm{~nm}$ InP-based diode lasers suffer poor lasing performance at hightemperature operation. ${ }^{1}$ Kondow and co-workers ${ }^{2}$ of Hitachi Corporation introduced the InGaAsN material system as a material system with enormous potential for realizing light emitters on GaAs in the wavelength regime of interest for optical communications, namely $1300-1550 \mathrm{~nm}$. The poor temperature characteristics of InP-based semiconductor lasers have led to enormous efforts in exploring the InGaAsN QW lasers, ${ }^{2-11}$ as well as other types of $1300 \mathrm{~nm}$ active regions on GaAs, as alternatives to realize high-performance QW lasers for high-temperature operation.

Unfortunately, early InGaAsN QW lasers suffer from poor lasing performance due to the utilization of nearly lattice-matched InGaAsN. ${ }^{2,3}$ The nearly lattice-matched or lattice-matched InGaAsN QW lasers require a relatively large $\mathrm{N}$ content of approximately $3 \%$ with an In content of $9 \%-12 \%$ to adjust the lattice constant back to that of an unstrained material system. Sato and co-workers ${ }^{4}$ of Ricoh Corporation in Japan, proposed the approach of utilizing a high In-content InGaAsN QW active region. The concept proposed was to utilize as high an In content as possible in the InGaAsN QW, such that a minimum amount of $\mathrm{N}$ content is required to push the peak emission wavelength to 1300 $\mathrm{nm}$. By utilizing this approach, Sato and co-workers ${ }^{4}$ were able to realize $1300 \mathrm{~nm}$ InGaAsN QW lasers with reasonable threshold current densities, on the order of $0.92-1.0 \mathrm{kA} / \mathrm{cm}^{2}$ for devices with a cavity length of approximately $1000 \mu \mathrm{m} .{ }^{4}$ Recently, various groups utilizing an In content as high as $30 \%-40 \%$ have been able to realize high-performance InGaAsN QW lasers in the wavelength regime of 1280-1310 $\mathrm{nm} .^{4-11}$

In our previous work, InGaAsN QW lasers with an In content of $40 \%$ and $\mathrm{N}$ content of only $0.5 \%$ have been realized with threshold current densities of only $210 \mathrm{~A} / \mathrm{cm}^{2}$ at an emission wavelength of $1295 \mathrm{~nm}^{7}$ From studies on InGaAsN QW lasers with an In content of $35 \%-43 \%,{ }^{12}$ we also observe a trend toward a reduction in the threshold current densities for $1300 \mathrm{~nm}$ InGaAsN QW lasers with increasing In content. Therefore, it is extremely important to realize

${ }^{a)}$ Electronic mail: tansu@cae.wisc.edu high-performance InGaAs QW lasers with a very long emission wavelength, such that it requires a minimal amount of $\mathrm{N}$ in the QW to push the emission wavelength to $1300 \mathrm{~nm}$.

In this work, we present high-performance InGaAs QW lasers with an emission wavelength beyond $1230 \mathrm{~nm}$, utilizing GaAsP tensile-strained buffer and barrier layers. The high $\mathrm{Al}$-content $\mathrm{AlGaAs}$ lower cladding layer introduces a slight compressively strained template prior to the growth of the highly strained active region. The tensile-strained GaAsP buffer layer (Fig. 1) acts to partially strain compensate for the QW growth template leading to an improved optical quality for the highly strained $\operatorname{InGaAs}(\mathrm{N}) \mathrm{QW}$. High optical luminescence intensity from the highly strained $\operatorname{InGaAs}(\mathrm{N})$ QW is only obtained with the utilization of the tensile buffer layer. ${ }^{6,7}$ Further studies are required to fully understand the role of the buffer layer in the observed improvement of the optical luminescence for the $\operatorname{In}_{0.4} \mathrm{Ga}_{0.6} \mathrm{As}(\mathrm{N}) \mathrm{QW}$.

All of the laser structures reported here are realized by low-pressure metalorganic chemical vapor deposition. Trimethylgallium, trimethylaluminium, and trimethylindium are used as the group-III sources. The group-V precursors used here are $\mathrm{AsH}_{3}$ and $\mathrm{PH}_{3}$. The dopant sources are $\mathrm{SiH}_{4}$ and dielthylzinc for the $n$ and $p$ dopants, respectively. The composition of the QW is characterized by high-resolution $\mathrm{x}$-ray diffraction experiments, and has been elaborated in our earlier work. $^{14}$

The schematic band diagram of the $1200 \mathrm{~nm}$ laser structure is shown in Fig. 1, which is identical with that of the laser structure previously studied for $1300 \mathrm{~nm}$ InGaAsN QW lasers $^{7}$ except for the active region. The active region is based on the $60 \AA \mathrm{In}_{0.4} \mathrm{Ga}_{0.6} \mathrm{As} \mathrm{QW}$, sandwiched by barrier

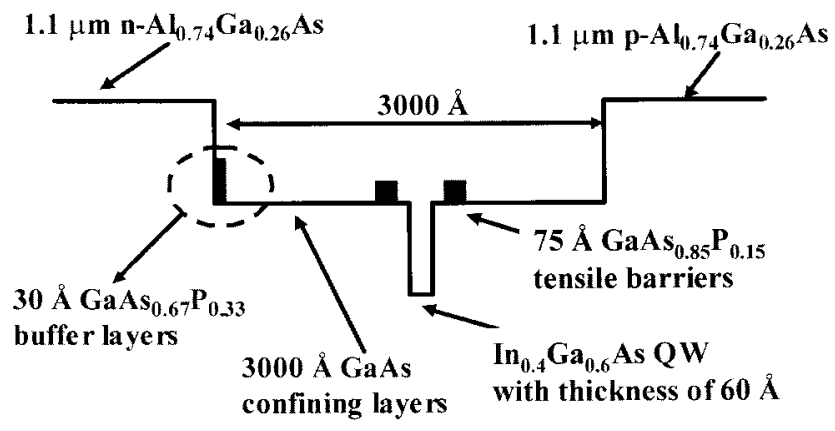

FIG. 1. Cross-sectional schematic conduction band diagram of the $\mathrm{In}_{0.4} \mathrm{Ga}_{0.6} \mathrm{As}$ QW laser with tensile-strained $\mathrm{GaAs}_{0.67} \mathrm{P}_{0.33}$ buffer and $\mathrm{GaAs}_{0.85} \mathrm{P}_{0.15}$ barrier layers. 


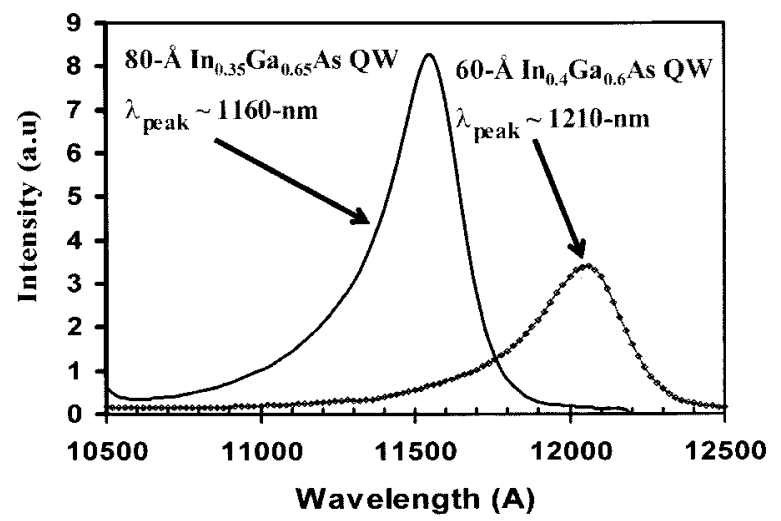

FIG. 2. Photoluminescence spectra comparison of $1170 \mathrm{~nm} \mathrm{In}_{0.35} \mathrm{Ga}_{0.65} \mathrm{As}$ $\mathrm{QW}$ and $1210 \mathrm{~nm} \mathrm{In}_{0.4} \mathrm{Ga}_{0.6} \mathrm{As} \mathrm{QW}$ active region.

regions of $100 \AA$ GaAs on each side. The strain compensation of the active region is provided by the $75 \AA$ $\mathrm{GaAs}_{0.85} \mathrm{P}_{0.15}$ tensile barriers, which are grown before and after the GaAs barrier regions. The optical confinement factor for the InGaAs QW is calculated as approximately $1.7 \%$. The growth of the active region and the optical confinement regions utilize an $\left[\mathrm{AsH}_{3}\right] / \mathrm{III}$ ratio in excess of 100 , at a reactor temperature of approximately $530{ }^{\circ} \mathrm{C}$. The $n$ - and p-cladding layers are based on an $\mathrm{Al}_{0.74} \mathrm{Ga}_{0.26} \mathrm{As}$ material system, grown at $775^{\circ} \mathrm{C}$ and $640^{\circ} \mathrm{C}$, respectively. Both cladding layers are designed with a doping level of approximately $1 \times 10^{18} \mathrm{~cm}^{-3}$. The tensile buffer layer consists of a $30 \AA \mathrm{GaAs}_{0.67} \mathrm{P}_{0.33}$, which we found to be crucial for the growth of the highly strained $\operatorname{InGaAs}(\mathrm{N})$ QW material system on top of a high Al-content lower cladding layer. ${ }^{6,7}$

The room-temperature photoluminescence of the $60 \AA$ $\mathrm{In}_{0.4} \mathrm{Ga}_{0.6} \mathrm{As} \mathrm{QW}$ active material is presented in Fig. 2, along with that of an $80 \AA \mathrm{In}_{0.35} \mathrm{Ga}_{0.65}$ As QW for comparison. The peak emission wavelength of the $\operatorname{In}_{0.4} \mathrm{Ga}_{0.6}$ As QW is measured at approximately $1210-1215 \mathrm{~nm}$, which is $50-60 \mathrm{~nm}$ longer than that of the $\operatorname{In}_{0.35} \mathrm{Ga}_{0.65}$ As QW. The reduction in the optical luminescence intensity of the $\mathrm{In}_{0.4} \mathrm{Ga}_{0.6} \mathrm{As}$ QW $(\Delta a / a=2.78 \%)$, in comparison to that of $\mathrm{In}_{0.35} \mathrm{Ga}_{0.65} \mathrm{As} \mathrm{QW}$ $(\Delta a / a=2.45 \%)$, is presumably a result of a slight degradation in the crystal quality due to the higher strain of the 1210 $\mathrm{nm}$ InGaAs QW.

The lasing characteristics are measured under a pulsed condition with a pulse width of $5 \mu$ s and duty cycle of $1 \%$. The measurements are performed on as-cleaved broad area laser devices, with an oxide-defined stripe width of $100 \mu \mathrm{m}$. The metal contacts are realized with $250 \AA$ Ti $/ 500 \AA \mathrm{Pt} / 1500$ $\AA \mathrm{Au}$ and $200 \AA \mathrm{Ge} / 1000 \AA \mathrm{GeAu} / 500 \AA \mathrm{Ni} / 3000 \AA \mathrm{Au}$ for $p$ and $\mathrm{n}$ contacts, respectively. The contact annealing of the devices is accomplished under forming gas $\left(10 \% \mathrm{H}_{2}\right.$ $+90 \% \mathrm{~N}_{2}$ ) at a temperature of $370{ }^{\circ} \mathrm{C}$ for duration of $30 \mathrm{~s}$.

The room-temperature $\left(T=20^{\circ} \mathrm{C}\right)$ lasing spectrum for the $60 \AA \mathrm{In}_{0.4} \mathrm{Ga}_{0.6} \mathrm{As}$ QW devices with a cavity length of $1000 \mu \mathrm{m}$ is measured as long as $1233 \mathrm{~nm}$, as shown in Fig. 3 . The lasing emission wavelengths range from $1216 \mathrm{~nm}$ to $1233 \mathrm{~nm}$, with little variation in threshold current densities. As shown in Fig. 3, the threshold current density of these $\mathrm{In}_{0.4} \mathrm{Ga}_{0.6} \mathrm{As}$ QW laser devices is found to be $90-92 \mathrm{~A} / \mathrm{cm}^{2}$ for measurements at a heat-sink temperature of $20^{\circ} \mathrm{C}$. The Downloaded 20 Dec 2006 to 128.104.198.71. Redistribution subject

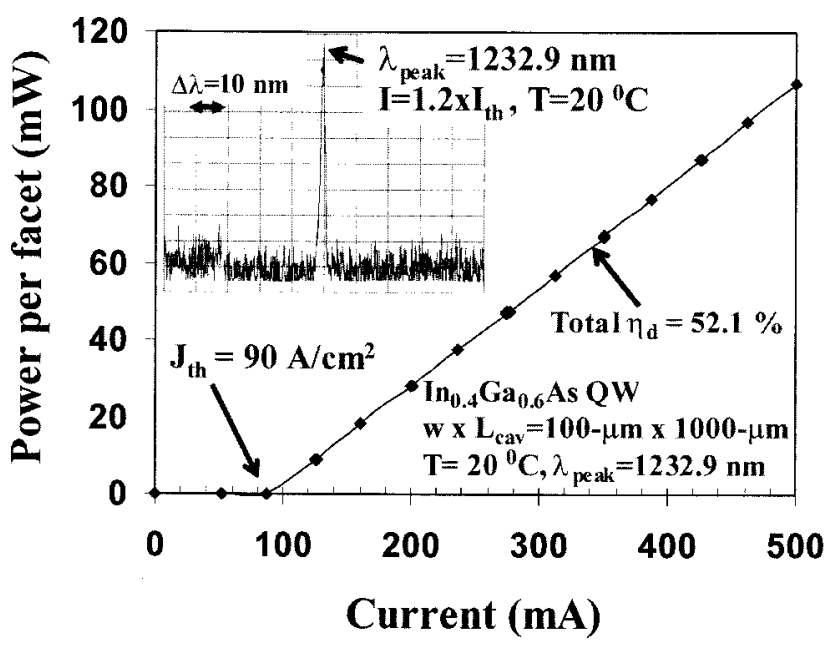

FIG. 3. The relation of output power per facet $(P)$ and the total injected current $(I)$ for $\operatorname{In}_{0.4} \mathrm{Ga}_{0.6}$ As QW lasers with a cavity length of $1000 \mu \mathrm{m}$ at a temperature of $20^{\circ} \mathrm{C}$. The inset shows the lasing spectrum at $20^{\circ} \mathrm{C}$.

total external differential quantum efficiency $\left(\eta_{d}\right)$ of the devices is measured as approximately $52.1 \%$.

The temperature characteristics of the threshold current densities $\left(T_{0}\right.$ values, with $\left.1 / T_{0}=\left(1 / J_{\mathrm{th}}\right) \cdot d J_{\mathrm{th}} / d T\right)$ and the external differential quantum efficiencies $\left(T_{1}\right.$ values, with $\left.1 / T_{1}=\left(-1 / \eta_{d}\right) \cdot d \eta_{d} / d T\right)$ of the $1233 \mathrm{~nm} \mathrm{In}_{0.4} \mathrm{Ga}_{0.6} \mathrm{As} \mathrm{QW}$ lasers are shown in Fig. 4. The temperature characterization is conducted from a temperature of $10^{\circ} \mathrm{C}$ up to a temperature of $100^{\circ} \mathrm{C}$, with temperature steps of $5^{\circ} \mathrm{C}$. In the temperature range of $10^{\circ} \mathrm{C}$ to $50^{\circ} \mathrm{C}$, the slope efficiency $\left(\eta_{d}\right)$ hardly decreases with temperature, resulting in a $T_{1}$ value of approximately $1250 \mathrm{~K}$ based on our best fit. For the temperature range of $50^{\circ} \mathrm{C}$ to $100^{\circ} \mathrm{C}$, we observe a significant drop of the $T_{1}$ value from $1250 \mathrm{~K}$ to approximately $480 \mathrm{~K}$. It is important to note that $T_{1}$ values of $1250 \mathrm{~K}$ and $480 \mathrm{~K}$ are significantly larger than those of $1300 \mathrm{~nm}$ InGaAsN QW lasers. For $1300 \mathrm{~nm}$ InGaAsN QW lasers with the same separate confinement heterostucture as the InGaAs active lasers and cavity length of $1000 \mu \mathrm{m}$, we previously reported $T_{1}$ value of $255 \mathrm{~K}$ for measurements in the temperature range of $20^{\circ} \mathrm{C}$ to $60^{\circ} \mathrm{C}$. The $T_{0}$ values are measured as 140 $\mathrm{K}$ and $105 \mathrm{~K}$ for measurements in the temperature ranges of $10-50{ }^{\circ} \mathrm{C}$ and $50-100{ }^{\circ} \mathrm{C}$, respectively. The lowering of $T_{0}$ and $T_{1}$ values at elevated temperatures are presumably driven by the thermionic carrier leakage processes. Neverthe-

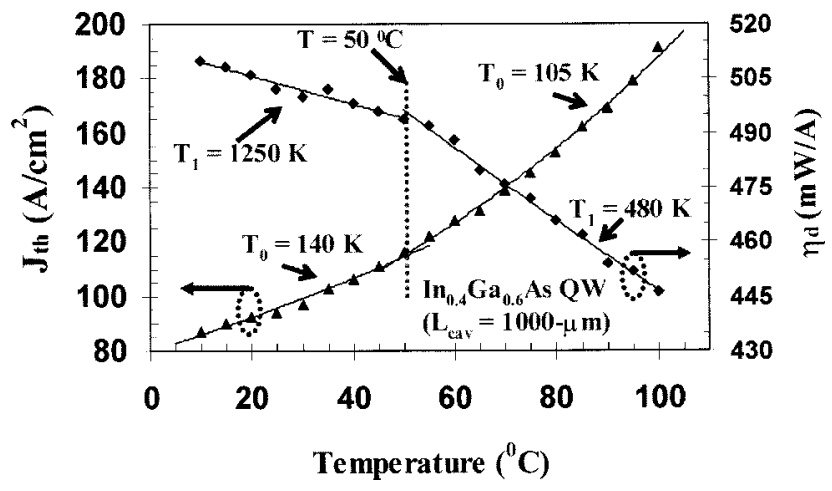

FIG. 4. Threshold current density $\left(J_{\text {th }}\right)$ and external differential quantum efficiency $\left(\eta_{d}\right)$ of $1233 \mathrm{~nm} \operatorname{In}_{0.4} \mathrm{Ga}_{0.6} \mathrm{As}$ QW lasers $\left(L_{\text {cav }}=1000 \mu \mathrm{m}\right)$ as a function of temperature in the range of $10^{\circ} \mathrm{C}$ to $100{ }^{\circ} \mathrm{C}$.

to AIP license or copyright, see http://apl.aip.org/apl/copyright.jsp 


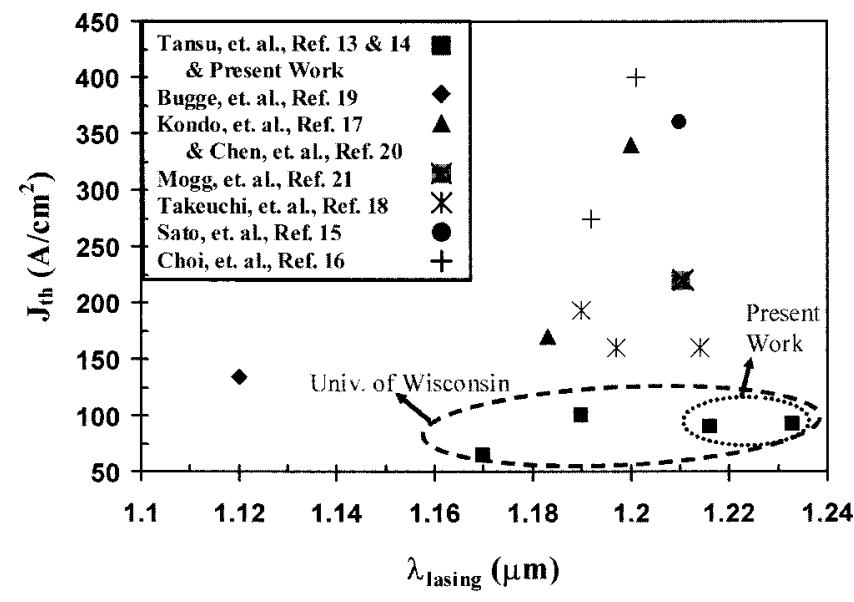

FIG. 5. Comparison of threshold current densities of InGaAs QW lasers in the $1100-1250 \mathrm{~nm}$ wavelength regime.

less, very-low threshold-current-densities of only $160 \mathrm{~A} / \mathrm{cm}^{2}$ and $190 \mathrm{~A} / \mathrm{cm}^{2}$ are achieved for $\operatorname{In}_{0.4} \mathrm{Ga}_{0.6} \mathrm{As}$ QW lasers $\left(L_{\text {cav }}=1000 \mu \mathrm{m}\right)$ at temperatures of $85^{\circ} \mathrm{C}$ and $100^{\circ} \mathrm{C}$, respectively.

Comparison of the lasing characteristics of the 1215$1233 \mathrm{~nm}$ InGaAs QW lasers with reported results in literature $^{13-21}$ is shown in Fig. 5. As the emission wavelength of the InGaAs QW lasers is extended, typically, their threshold current densities increase rapidly. Previously, very low reported threshold current densities for InGaAs QW lasers on GaAs beyond emission wavelength of $1210 \mathrm{~nm}$ were realized by Takeuchi and co-workers ${ }^{18}$ with room-temperature threshold current densities of $160 \mathrm{~A} / \mathrm{cm}^{2}$ for devices with cavity length of $1000 \mu \mathrm{m}$. In our present work, we recorded threshold current densities of only $90-92 \mathrm{~A} / \mathrm{cm}^{2}$ for straincompensated InGaAs QW lasers up to emission wavelength of $1233 \mathrm{~nm}$. It is also important to note that we observe only a very slight dependence of the threshold current densities on emission wavelengths from $1170 \mathrm{~nm}$ to $1233 \mathrm{~nm}$, which may be a result of the utilization of the GaAsP tensile-strained barriers.

In summary, high-performance InGaAs QW lasers have been realized with lasing performance up to an emission wavelength of $1233 \mathrm{~nm}$. The realization of diode lasers with a room-temperature emission wavelength of $1233 \mathrm{~nm}$, represents the longest emission wavelength realized with only an InGaAs QW active region on a GaAs substrate. The thresh- old current densities of only $90 \mathrm{~A} / \mathrm{cm}^{2}$ and $190 \mathrm{~A} / \mathrm{cm}^{2}$ are measured for laser devices with a cavity length of $1000 \mu \mathrm{m}$ at temperatures of $20^{\circ} \mathrm{C}$ and $100{ }^{\circ} \mathrm{C}$, respectively. These reported threshold current densities represent among the lowest values for InGaAs QW diode lasers on GaAs in the wavelength regime beyond $1200 \mathrm{~nm}$. No evidence of a significant increase in the threshold current of the InGaAs QW lasers, with increasing wavelength beyond $1200 \mathrm{~nm}$, indicates the potential for achieving high-performance diode lasers on GaAs substrates with emission wavelength even beyond $1233 \mathrm{~nm}$ utilizing only an InGaAs QW active material.

${ }^{1}$ G. L. Belenky, C. L. Reynolds, Jr., D. V. Donetsky, G. E. Shtengel, M. S. Hybertsen, M. A. Alam, G. A. Baraff, R. K. Smith, R. F. Kazarinov, J. Winn, and L. E. Smith, IEEE J. Quantum Electron. 35, 1515 (1999).

${ }^{2}$ M. Kondow, T. Kitatani, S. Nakatsuka, M. C. Larson, K. Nakahara, Y. Yazawa, M. Okai, and K. Uomi, IEEE J. Sel. Top. Quantum Electron. 3, 719 (1997).

${ }^{3}$ J. S. Harris, Jr., IEEE J. Sel. Top. Quantum Electron. 6, 1145 (2000).

${ }^{4}$ S. Sato, Jpn. J. Appl. Phys., Part 1 39, 3403 (2000).

${ }^{5}$ D. A. Livshits, A. Y. Egorov, and H. Riechert, Electron. Lett. 36, 1381 (2000).

${ }^{6}$ N. Tansu and L. J. Mawst, IEEE Photonics Technol. Lett. 14, 444 (2002).

${ }^{7}$ N. Tansu, N. J. Kirsch, and L. J. Mawst, Appl. Phys. Lett. 81, 2523 (2002).

${ }^{8}$ J. Wei, F. Xia, C. Li, and S. R. Forrest, IEEE Photonics Technol. Lett. 14, 597 (2002).

${ }^{9}$ K. D. Choquette, J. F. Klem, A. J. Fischer, O. Blum, A. A. Allerman, I. J. Fritz, S. R. Kurtz, W. G. Breiland, R. Sieg, K. M. Geib, J. W. Scott, and R. L. Naone, Electron. Lett. 36, 1388 (2000).

${ }^{10}$ W. Ha, V. Gambin, M. Wistey, S. Bank, S. Kim, and J. S. Harris, Jr., IEEE Photonics Technol. Lett. 14, 591 (2002).

${ }^{11}$ C. S. Peng, T. Jouhti, P. Laukkanen, E.-M. Pavelescu, J. Konttinen, W. Li, and M. Pessa, IEEE Photonics Technol. Lett. 14, 275 (2002).

${ }^{12} \mathrm{~N}$. Tansu, J. Y. Yeh, and L. J. Mawst (unpublished).

${ }^{13}$ N. Tansu and L. J. Mawst, IEEE Photonics Technol. Lett. 13, 179 (2001).

${ }^{14}$ N. Tansu, Y. L. Chang, T. Takeuchi, D. P. Bour, S. W. Corzine, M. R. T. Tan, and L. J. Mawst, IEEE J. Quantum Electron. 38, 640 (2002).

${ }^{15}$ S. Sato and S. Satoh, Jpn. J. Appl. Phys., Part 2 38, L990 (1999).

${ }^{16}$ W. Choi, P. D. Dapkus, and J. Jewell, IEEE Photonics Technol. Lett. 11, 1572 (1999)

${ }^{17}$ T. Kondo, D. Schlenker, T. Miyamoto, Z. Chen, M. Kawaguchi, E. Gouardes, F. Koyama, and K. Iga, Jpn. J. Appl. Phys., Part 1 40, 467 (2000).

${ }^{18}$ T. Takeuchi, Y.-L. Chang, A. Tandon, D. Bour, S. Corzine, R. Twist, M. Tan, and H.-C. Luan, Appl. Phys. Lett. 80, 2445 (2002).

${ }^{19}$ F. Bugge, G. Erbert, J. Fricke, S. Gramlich, R. Staske, H. Wenzel, U. Zeimer, and M. Weyers, Appl. Phys. Lett. 79, 1965 (2001).

${ }^{20}$ Z. B. Chen, D. Schlenker, F. Koyama, T. Miyamoto, A. Matsutani, and K. Iga, in Proceedings of the APCC/OECC'99, Beijing, China, 1999, Vol. 2, p. 1311.

${ }^{21}$ S. Mogg, N. Chitica, R. Schatz, and M. Hammar, Appl. Phys. Lett. 81, 2334 (2002) 